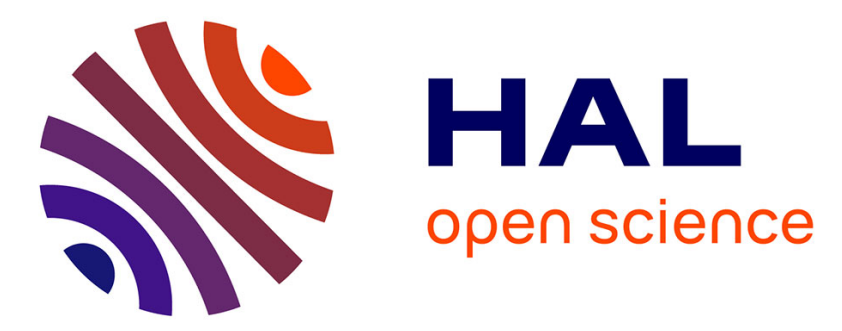

\title{
A novel biallelic splice site mutation of TECTA causes moderate to severe hearing impairment in an Algerian family
}

Abdeslam Behlouli, C. Bonnet, S. Abdi, M. Hasbellaoui, F. Boudjenah, J.-P. Hardelin, M. Louha, M. Makrelouf, F. Ammar-Khodja, A. Zenati, et al.

\section{To cite this version:}

Abdeslam Behlouli, C. Bonnet, S. Abdi, M. Hasbellaoui, F. Boudjenah, et al.. A novel biallelic splice site mutation of TECTA causes moderate to severe hearing impairment in an Algerian family. International Journal of Pediatric Otorhinolaryngology Extra, 2016, 10.1016/j.ijporl.2016.04.040 . hal-01321430

\section{HAL Id: hal-01321430 \\ https://hal.sorbonne-universite.fr/hal-01321430}

Submitted on 25 May 2016

HAL is a multi-disciplinary open access archive for the deposit and dissemination of scientific research documents, whether they are published or not. The documents may come from teaching and research institutions in France or abroad, or from public or private research centers.
L'archive ouverte pluridisciplinaire HAL, est destinée au dépôt et à la diffusion de documents scientifiques de niveau recherche, publiés ou non, émanant des établissements d'enseignement et de recherche français ou étrangers, des laboratoires publics ou privés. 


\section{A novel biallelic splice site mutation of TECTA causes moderate to severe hearing impairment in an Algerian family}

Behlouli A. ${ }^{1,2}$, Bonnet C. ${ }^{4}$, Abdi S. ${ }^{2,5}$, Hasbellaoui M. ${ }^{6}$, Boudjenah F. ${ }^{6}$, Hardelin J.-P. ${ }^{7}$, Louha M. ${ }^{8}$, Makrelouf M. ${ }^{2,3}$, Ammar-Khodja F. ${ }^{1}$, Zenati A. ${ }^{2,3}$ and Petit C., ${ }^{4,9}$

${ }^{1}$ Département de Biologie et Physiologie des Organismes, Faculté des sciences biologiques, Université des sciences et de la technologie Houari Boumédiène, El Alia, Bab-Ezzouar, Alger, Algérie

${ }^{2}$ Laboratoire de Biochimie Génétique-Université Alger 1

${ }^{3}$ Service de Biologie -CHU de Bab El Oued -Alger

${ }^{4}$ INSERM UMRS1120, Sorbonne Universités, UPMC Université Paris 06, Institut de la Vision, Paris, France

${ }^{5}$ Laboratoire central de biologie, CHU Frantz Fanon, Faculté de médecine, Université Saad Dahleb, Blida, Algérie

${ }^{6}$ Service ORL, Unité Belloua, Centre Hospitalier Universitaire Mohamed Nedir, Tizi Ouzou, Algérie

${ }^{7}$ Unité de Génétique et Physiologie de l'Audition, INSERM UMRS1120, Institut Pasteur, Paris, France

${ }^{8}$ Service de Biochimie et de Biologie Moléculaire, Hôpital Armand Trousseau, APHP, Paris, France

${ }^{9}$ Collège de France, Paris, France

Keywords: Whole exome sequencing, congenital deafness, Algeria 


\begin{abstract}
Congenital deafness is certainly one of the most common monogenic diseases in humans, but it is also one of the most genetically heterogeneous, which makes molecular diagnosis challenging in most cases. Whole-exome sequencing in two out of three Algerian siblings affected by recessively-inherited, moderate to severe sensorineural deafness allowed us to identify a novel splice donor site mutation $(\mathrm{c} .5272+1 \mathrm{G}>\mathrm{A})$ in the gene encoding $\alpha$-tectorin, a major component of the cochlear tectorial membrane. The mutation was present at the homozygous state in the three affected siblings, and at the heterozygous state in their unaffected, consanguineous parents. To our knowledge, this is the first reported TECTA mutation leading to the DFNB21 form of hearing impairment among Maghrebian individuals suffering from congenital hearing impairment, which further illustrates the diversity of the genes involved in congenital deafness in the Maghreb.
\end{abstract}




\section{Introduction}

Deafness is the most common congenital sensory defect. In developed countries, it is diagnosed in 1 out of 500 newborns (1-3). In about $70 \%$ of the cases, deafness is nonsyndromic, which means isolated (4). Congenital deafness is almost exclusively inherited as a monogenic disease, but a great variety of genes can be involved. It has been estimated that about $80 \%$ of the genetic forms of early onset nonsyndromic deafness are autosomal recessive (DFNB) forms, and 20\% are autosomal dominant (DFNA) forms (5). Sixty DFNB genes and 32 DFNA genes have been identified so far, and many more remain to be discovered (Hereditary Hearing Loss Homepage: http://hereditaryhearingloss.org/). We report the identification of a new splice site mutation in the DFNB21 gene TECTA (6), encoding $\alpha$ tectorin, in three Algerian siblings affected by prelingual, moderate to severe sensorineural deafness.

\section{Patients and methods}

This study was approved by the local ethics committee. Informed consent for genetic testing was obtained from the adult individuals or, in the case of minor individuals, from their parents.

\section{Patients}

Sixty-seven Algerian families with at least two members affected by prelingual bilateral deafness were recruited. Affected individuals underwent clinical examination, including puretone audiometry, in otolaryngology centers in Algiers, Algeria. In the vast majority of cases, deaf children were born to consanguineous normal-hearing parents, therefore indicating a DFNB form of deafness. Here, we report on such a family with three siblings affected by prelingual, moderate to severe, bilateral sensorineural hearing impairment (Figure 1A). All 
three affected individuals underwent pure-tone audiometry in a soundproof room, with recording of air-conduction and bone-conduction thresholds. Air-conduction pure-tone average (ACPTA) threshold in the conversational frequencies $(0.5,1,2$, and $4 \mathrm{kHz})$ was measured for each ear, and its value for the best ear was used to define the severity of deafness: mild $(20 \mathrm{~dB}<$ ACPTA $\leq 39 \mathrm{~dB})$, moderate $(40 \mathrm{~dB}<$ ACPTA $\leq 69 \mathrm{~dB})$, severe $(70$ $\mathrm{dB}<\mathrm{ACPTA} \leq 89 \mathrm{~dB})$, or profound $(\geq 90 \mathrm{~dB})$. Temporal bone CT scan revealed no inner ear malformation. The affected siblings had begun to walk independently at the age of nine months, and did not have any balance problems. Clinical examination failed to detect additional symptoms indicating a syndromic form of deafness, and neither proteinuria nor hematuria was detected. Both parents did not show any sign of hearing impairment.

\section{Exome sequencing and Sanger sequencing}

Genomic DNA was extracted from blood samples, using the Promega Wizard Genomic DNA Purification Kit (Promega, Madison, MI, USA, Cat. \# A1120). Whole-exome sequencing was performed as previously described (7) with minor modifications, using the SureSelect V5 capture kit (Agilent) and HiSeq 2000 sequencer (Illumina). Bioinformatics analysis of sequence data was based on the pipeline provided by Illumina (CASAVA 1.8), and the algorithm ELANDv2e (Malony alignment and multi-seed mismatch reducing artifact) was used for sequence alignment. To validate the TECTA mutation and study its segregation by the Sanger technique, specific primers were designed using Primer3 (http://bioinfo.ut.ee/primer3-0.4.0/). The sequences of the primers are available on request.

\section{Results and discussion}

Among the DFNB families without mutations identified in the promoter, non-coding and coding exons of GJB2, the gene most frequently involved in Mediterranean countries (8-10), 
we selected a family based on the auditory phenotype of the three affected siblings (IV.1, IV.2, and IV.3), who were affected by prelingual, symmetric, moderate to severe hearing impairment, with audiograms showing down-sloping curves (Figure 1C). We did not detect mutations in LRTOMT, OTOF, and TMC1, three DFNB genes previously shown to be involved in Maghrebian populations (11-14), by Sanger sequencing of the coding exons in patient IV.1. We therefore carried out whole-exome sequencing on pooled genomic DNA from two affected siblings, as previously described (7). All variants present in the dBSNP132, 1000 genomes, Exome Variant Server, and HapMap databases with a prevalence greater than $0.01 \%$ were excluded. As the parents were consanguineous, we hypothesized that the causal mutations in the affected siblings were present at the homozygous state. Using these filters, we identified a previously unreported missense mutation in ADAMTSL2, c.2305G>A (p.Gly769Arg), which was predicted to be damaging by the MutationTaster, SIFT, and PolyPhen2 algorithms, an indel mutation, c.46_47insCTG (p.Leu16delinsProVal), in BRI3BP, and the c.5272+1G>A splice site mutation in TECTA, a gene involved both in autosomal dominant (DFNA8/12) and autosomal recessive (DFNB21) forms of deafness $(6,15)$ (Figure 1B). The segregation of the ADAMTSL2 missense mutation in this family was compatible with a causal role in the hearing impairment as the mutation was present at the homozygous state in the three affected siblings and at the heterozygous state in their normal-hearing parents. However, mutations of ADAMTSL2 cause geleophysic dysplasia characterized by short stature, abnormalities of the hands and feet, and distinct facial features (16), but none of these clinical signs was present in any of the deaf siblings, thus indicating that the ADAMTSL2 sequence variant was a nonpathogenic rare polymorphism. We also excluded the BRI3BP mutation because the third affected child (IV.3) carried this mutation at the heterozygous state. By contrast, the TECTA mutation, predicted to suppress the splice donor site of intron 15 (Max Ent, NNsplice, Human Splicing Finder, and Genesplicer algorithms), 
was present at the homozygous state in the three affected siblings and at the heterozygous state in their parents, and it was not present in 120 Algerian control individuals. We therefore conclude that this mutation, which is expected to result in abnormal splicing of the TECTA mRNA, is responsible for the hearing impairment in this family.

TECTA consists of 23 exons. It encodes a 2155 amino acid secreted protein, $\alpha$-tectorin, which is one of the main noncollagenous proteins of the cochlear tectorial membrane $(17,18)$. This ribbon-like strip of extracellular matrix lies over the cochlear hair cells and is critical both for the mechanical amplification of sound stimuli by the outer hair cells and for their transmission to the inner hair cells, which are the genuine sensory cells $(19,20)$. Targeted deletion of Tecta in mice results in a detachment of the tectorial membrane from the sensory epithelium (19). The protein is composed of a nidogen (NIDO)-like domain, a large zonadhesin (ZA) region containing three trypsin inhibitor-like (TIL) cysteine-rich domains, four C8 domains (with eight conserved cysteine residues), a von Willebrand factor type C (vWFC) and four von Willebrand factor type D (vWFD) domains, and a zona pellucida (ZP) domain (21). The TECTA splice site mutation identified in the Algerian family is expected to result in a truncated protein of 1765 amino acids lacking the ZP domain (Figure 1D).

TECTA has been implicated both in autosomal dominant (DFNA) and autosomal recessive (DFNB) forms of deafness $(6,15)$. To date, 41 and 20 different TECTA mutations have been reported to cause DFNA8/12 and DFNB21, respectively (Table 1). To our knowledge, none of the deaf individuals carrying the TECTA mutations previously reported was originating from the Maghreb. All the mutations reported in DFNA8/12, except four, are missense mutations, whereas those reported in DFNB21 are mainly, but not exclusively, truncating (i.e., nonsense, frameshift, or splice site) mutations. Of note, only two splice-site mutations leading to DFNB21 (c.2941+1G>A and c.6162+3insT) have been reported so far. The DFNA8/12 missense mutations affect amino-acid residues spread across the protein, and 
produce different abnormal hearing phenotypes, with either pre- or post-lingual onset, depending on the affected protein domain. By contrast, most DFNB21 mutations are associated with similar audiometric patterns of moderate-to-severe prelingual hearing impairment, as observed in this family $(6,22,23)$. 


\section{Acknowledgments}

We thank all the family members for their cooperation and support. This work was supported by grants from LHW-Stiftung, European Research Council (ERC-2011-AdG 294570), Foundation BNP Paribas, "Lifesenses" Labex, the Tassili Project, and the Algerian government.

\section{Competing interest}

The authors declare that they have no competing interest. 


\section{References}

1.Marazita ML, Ploughman LM, Rawlings B, Remington E, Arnos KS, Nance WE. Genetic epidemiological studies of early-onset deafness in the U.S. school-age population. AmJ Med Genet. 1993;46:486-91.

2. Morton NE. Genetic epidemiology of hearing impairment. Ann Ny Acad Sci. 1991;630:16-31.

3.Smith RJH, Bale JF, White KR. Sensorineural hearing loss in children. Lancet. 2005;365:879-90.

4.Smith RJH, Van Camp G. Nonsyndromic hearing loss and deafness, DFNB1. In: Pagon RA, Adam MP, Ardinger HH, Wallace SE, Amemiya A, Bean LJH, et al., editors. GeneReviews(R). Seattle (WA)1993.

5.Morton CC, Nance WE. Current concepts: Newborn hearing screening - A silent revolution. New Engl J Med. 2006;354:2151-64.

6.Mustapha M, Weil D, Chardenoux S, Elias S, El-Zir E, Beckmann JS, et al. An alpha-tectorin gene defect causes a newly identified autosomal recessive form of sensorineural pre-lingual nonsyndromic deafness, DFNB21. Hum Mol Genet. 1999;8:409-12.

7.Delmaghani S, Aghaie A, Michalski N, Bonnet C, Weil D, Petit C. Defect in the gene encoding the EAR/EPTP domain-containing protein TSPEAR causes DFNB98 profound deafness. Hum Mol Genet. 2012;21:3835-44.

8.Abidi O, Boulouiz R, Nahili H, Bakhouch K, Wakrim L, Rouba H, et al. Carrier frequencies of mutations/polymorphisms in the connexin 26 gene (GJB2) in the Moroccan population. Genet Test. 2008;12:569-74.

9.Ammar-Khodja F, Faugere V, Baux D, Giannesini C, Leonard S, Makrelouf M, et al. Molecular screening of deafness in Algeria: High genetic heterogeneity involving DFNB1 and the Usher loci, DFNB2/USH1B, DFNB12/USH1D and DFNB23/USH1F. Eur J Med Genet. 2009;52:174-9.

10.Riahi Z, Hammami $H$, Ouragini $H$, Messai $H$, Zainine R, Bouyacoub $Y$, et al. Update of of the spectrum of GJB2 gene mutations in Tunisian families with autosomal recessive nonsyndromic hearing loss. Gene. 2013;525:1-4.

11.Charif M, Bounaceur S, Abidi O, Nahili $H$, Rouba $H$, Kandil M, et al. The c.242G>A mutation in LRTOMT gene is responsible for a high prevalence of deafness in the Moroccan population. Molecular biology reports. 2012;39:11011-6.

12.Riahi Z, Bonnet C, Zainine R, Louha M, Bouyacoub Y, Laroussi N, et al. Whole exome sequencing identifies new causative mutations in Tunisian families with non-syndromic deafness. Plos One. 2014;9:e99797.

13.Ammar-Khodja F, Bonnet C, Dahmani M, Ouhab S, Lefevre GM, Ibrahim H, et al. Diversity of the causal genes in hearing impaired Algerian individuals identified by whole exome sequencing. Mol Genet Genomic Med. 2015;3:189-96.

14.Ben Said M, Hmani-Aifa M, Amar I, Baig SM, Mustapha M, Delmaghani S, et al. High frequency of the p.R34X mutation in the TMC1 gene associated with nonsyndromic hearing loss is due to founder effects. Genet Test Mol Bioma. 2010;14:307-11.

15.Verhoeven K, Van Laer L, Kirschhofer K, Legan K, Hughes D, Verstreken M, et al. Non-syndromic deafness DFNA12 is caused by mutations in alpha-tectorin. Eur J Hum Genet. 1998;6:38-

16.Le Goff C, Morice-Picard F, Dagoneau N, Wang LW, Perrot C, Crow YJ, et al. ADAMTSL2 mutations in geleophysic dysplasia demonstrate a role for ADAMTS-like proteins in TGF-beta bioavailability regulation. Nat Genet. 2008;40:1119-23.

17.Legan PK, Rau A, Keen JN, Richardson GP. The mouse tectorins. Modular matrix proteins of the inner ear homologous to components of the sperm-egg adhesion system. The Journal of biological chemistry. 1997;272:8791-801.

18.Richardson GP, Forge A, Kros CJ, Fleming J, Brown SDM, Steel KP. Myosin VIIA is required for aminoglycoside accumulation in cochlear hair cells. J Neurosci. 1997;17:9506-19.

19.Legan PK, Lukashkina VA, Goodyear RJ, KossI M, Russell IJ, Richardson GP. A targeted deletion in alpha-tectorin reveals that the tectorial membrane is required for the gain and timing of cochlear feedback. Neuron. 2000;28:273-85. 
20.Lukashkin AN, Legan PK, Weddell TD, Lukashkina VA, Goodyear RJ, Welstead LJ, et al. A mouse model for human deafness DFNB22 reveals that hearing impairment is due to a loss of inner hair cell stimulation. PNAS. 2010;109:19351-6.

21.Choi BY, Kim J, Chung J, Kim AR, Mun SJ, Kang SI, et al. Whole-exome sequencing identifies a novel genotype-phenotype correlation in the entactin domain of the known deafness gene TECTA. Plos One. 2014;9(5).

22.Meyer NC, Alasti F, Nishimura CJ, Imanirad P, Kahrizi K, Riazalhosseini Y, et al. Identification of three novel TECTA mutations in Iranian families with autosomal recessive nonsyndromic hearing impairment at the DFNB21 locus. Am J Med Genet. 2007;143A:1623-9.

23.Naz S, Alasti F, Mowjoodi A, Riazuddin S, Sanati MH, Friedman TB, et al. Distinctive audiometric profile associated with DFNB21 alleles of TECTA. J Med Genet. 2003;40:360-3.

24.Su Y, Tang WX, Gao X, Yu F, Dai ZY, Zhao JD, et al. A novel mutation in the TECTA gene in a Chinese family with autosomal dominant nonsyndromic hearing loss. PLoS One. 2014;9:e89240.

25. Hildebrand MS, Morin M, Meyer NC, Mayo F, Modamio-Hoybjor S, Mencia A, et al. DFNA8/12 caused by TECTA mutations is the most identified subtype of nonsyndromic autosomal dominant hearing loss. Hum Mutat. 2011;32:825-34.

26.Miyagawa M, Nishio SY, Ikeda T, Fukushima K, Usami S. Massively parallel DNA sequencing successfully identifies new causative mutations in deafness genes in patients with cochlear implantation and EAS. PLoS One. 2013;8:e75793.

27. Hutchin T, Coy NN, Conlon H, Telford E, Bromelow K, Blaydon D, et al. Assessment of the genetic causes of recessive childhood non-syndromic deafness in the UK - implications for genetic testing. Clin Genet. 2005;68:506-12.

28.Choi BY, Kim J, Chung J, Kim AR, Mun SJ, Kang SI, et al. Whole-exome sequencing identifies a novel genotype-phenotype correlation in the entactin domain of the known deafness gene TECTA. PLoS One. 2014;9:e97040.

29.Vozzi D, Morgan A, Vuckovic D, D'Eustacchio A, Abdulhadi K, Rubinato E, et al. Hereditary hearing loss: a 96 gene targeted sequencing protocol reveals novel alleles in a series of Italian and Qatari patients. Gene. 2014;542:209-16.

30. Sagong B, Park R, Kim YH, Lee KY, Baek JI, Cho HJ, et al. Two novel missense mutations in the TECTA gene in Korean families with autosomal dominant nonsyndromic hearing loss. Ann Clin Lab Sci. 2010;40:380-5.

31.Yang T, Wei X, Chai Y, Li L, Wu H. Genetic etiology study of the non-syndromic deafness in Chinese Hans by targeted next-generation sequencing. Orphanet J Rare Dis. 2013;8:85.

32.King DA, Fitzgerald TW, Miller R, Canham N, Clayton-Smith J, Johnson D, et al. A novel method for detecting uniparental disomy from trio genotypes identifies a significant excess in children with developmental disorders. Genome Res. 2014;24:673-87.

33.Balciuniene J, Dahl N, Jalonen P, Verhoeven K, Van Camp G, Borg E, et al. Alpha-tectorin involvement in hearing disabilities: one gene--two phenotypes. Hum Genet. 1999;105:211-6.

34.Babanejad M, Fattahi Z, Bazazzadegan N, Nishimura C, Meyer N, Nikzat N, et al. A comprehensive study to determine heterogeneity of autosomal recessive nonsyndromic hearing loss in Iran. Am J Med Genet. 2012;158A:2485-92.

35.Moteki H, Nishio SY, Hashimoto S, Takumi Y, Iwasaki S, Takeichi N, et al. TECTA mutations in Japanese with mid-frequency hearing loss affected by zona pellucida domain protein secretion. J Hum Genet. 2012;57:587-92.

36.Pfister M, Thiele H, Van Camp G, Fransen E, Apaydin F, Aydin O, et al. A genotype-phenotype correlation with gender-effect for hearing impairment caused by TECTA mutations. Cell Physiol Biochem. 2004;14:369-76.

37.Alloisio N, Morle L, Bozon M, Godet J, Verhoeven K, Van Camp G, et al. Mutation in the zonadhesin-like domain of alpha-tectorin associated with autosomal dominant non-syndromic hearing loss. Eur J Hum Genet. 1999;7:255-8. 
38.Shahin H, Walsh T, Rayyan AA, Lee MK, Higgins J, Dickel D, et al. Five novel loci for inherited hearing loss mapped by SNP-based homozygosity profiles in Palestinian families. Eur J Hum Genet. 2010;18(4):407-13.

39.Sagong B, Park HJ, Lee KY, Kim UK. Identification and functional characterization of novel compound heterozygotic mutations in the TECTA gene. Gene. 2012;492:239-43.

40.Diaz-Horta O, Duman D, Foster J, 2nd, Sirmaci A, Gonzalez M, Mahdieh N, et al. Whole-exome sequencing efficiently detects rare mutations in autosomal recessive nonsyndromic hearing loss. PLoS One. 2012;7:e50628.

41.Abe S, Yamaguchi T, Usami S. Application of deafness diagnostic screening panel based on deafness mutation/gene database using invader assay. Genet Test. 2007;11:333-40.

42.Collin RW, de Heer AM, Oostrik J, Pauw RJ, Plantinga RF, Huygen PL, et al. Mid-frequency DFNA8/12 hearing loss caused by a synonymous TECTA mutation that affects an exonic splice enhancer. Eur J Hum Genet. 2008;16:1430-6.

43.Verhoeven K, Van Laer L, Kirschhofer K, Legan PK, Hughes DC, Schatteman I, et al. Mutations in the human alpha-tectorin gene cause autosomal dominant non-syndromic hearing impairment. Nat Genet. 1998;19:60-2.

44.Moreno-Pelayo MA, del Castillo I, Villamar M, Romero L, Hernandez-Calvin FJ, Herraiz C, et al. A cysteine substitution in the zona pellucida domain of alpha-tectorin results in autosomal dominant, postlingual, progressive, mid frequency hearing loss in a Spanish family. J Med Genet. 2001;38:E13.

45.Kim AR, Chang MY, Koo JW, Oh SH, Choi BY. Novel TECTA mutations identified in stable sensorineural hearing loss and their clinical implications. Audiol Neurootol. 2014;20:17-25.

46.Plantinga RF, de Brouwer AP, Huygen PL, Kunst HP, Kremer H, Cremers CW. A novel TECTA mutation in a Dutch DFNA8/12 family confirms genotype-phenotype correlation. J Assoc Res Otolaryngol. 2006;7:173-81.

47.Li Z, Guo Y, Lu Y, Li J, Jin Z, Li H, et al. Identification of a ovel TECTA mutation in a Chinese DFNA8/12 family with prelingual progressive sensorineural hearing impairment. PLoS One. 2013;8:e70134.

48.Bai H, Yang X, Temuribagen, Guilan, Suyalatu, Narisu, et al. A rare novel mutation in TECTA causes autosomal dominant nonsyndromic hearing loss in a Mongolian family. BMC Med Genet. 2014;15:34. 49.Iwasaki S, Harada D, Usami S, Nagura M, Takeshita T, Hoshino T. Association of clinical features with mutation of TECTA in a family with autosomal dominant hearing loss. Arch Otolaryngol Head Neck Surg. 2002;128:913-7.

50.Alasti F, Sanati MH, Behrouzifard AH, Sadeghi A, de Brouwer AP, Kremer H, et al. A novel TECTA mutation confirms the recognizable phenotype among autosomal recessive hearing impairment families. Int J Pediatr Otorhinolaryngol. 2008;72:249-55. 
Figure legend

Figure 1: Clinical and molecular data in the patients harboring the splice site mutation

in TECTA. (A) Segregation of the TECTA mutation in the family. The + and - signs indicate the wild-type and mutated alleles, respectively. (B) Partial DNA sequencing chromatograms showing the mutation (arrow). (C) Air-conduction audiometric curves for both ears in patients IV.2 (open diamonds) and IV.3 (open circles) at the ages of 8 and 9 years, respectively. (D) Schematic representations of TECTA and $\alpha$-tectorin. * indicates the position of the mutation in intron 15. Abbreviations: NIDO, nidogen-like domain (blue); vWFC, von Willebrand factor type $\mathrm{C}$ domain (purple); von Willebrand factor type D domain (yellow); C8, eight conserved cysteine residues (red); TIL, trypsin inhibitor-like cysteine-rich domain (green); ZP, zona pellucida (turquoise). 
Table 1: List of the TECTA mutations reported in DFNA8/12 and DFNB21

\begin{tabular}{|c|c|c|c|c|c|c|c|c|c|}
\hline $\begin{array}{c}\text { Inheritance } \\
\text { pattern }\end{array}$ & TECTA mutation & Exon & $\begin{array}{l}\text { Protein } \\
\text { domain }\end{array}$ & $\begin{array}{c}\text { Severity of } \\
\text { deafness }\end{array}$ & $\begin{array}{c}\text { Age of } \\
\text { onset }\end{array}$ & Progression & $\begin{array}{l}\text { Affected sound } \\
\text { frequencies }\end{array}$ & Family origin & Reference \\
\hline $\mathrm{AD}$ & $\begin{array}{c}\text { c.257_262delinsGCT; } \\
\text { p.Ser86_Pro88delinsCysSer }\end{array}$ & 3 & & moderate & postlingual & progressive & all & Chinese & {$[24]$} \\
\hline $\mathrm{AR}$ & c.266delT; p.Leu89Argfs*34 & 3 & ENT & $\begin{array}{c}\text { moderate to } \\
\text { severe }\end{array}$ & prelingual & stable & mid & Iranian & [22] \\
\hline $\mathrm{AD}$ & c.589G>A; p.Asp197Asn & 4 & ENT & & postlingual & stable & mid & American & [25] \\
\hline AR & c.596delT; p.Leu199Argfs*7 & 4 & ENT & profound & prelingual & progressive & mid & Japanese & [26] \\
\hline $\mathrm{AD}$ & c.632T>C; p.Phe211Ser & 5 & ENT & & postlingual & stable & mid & Spanish & {$[25]$} \\
\hline AR & c.651dup; p.Asn218Glnfs*31 & 5 & ENT & moderate & prelingual & stable & all & Iranian & [23] \\
\hline AR & $\begin{array}{l}\text { c.654_657delTTTC; } \\
\text { p.Phe219Serfs*12 }\end{array}$ & 5 & ENT & $\begin{array}{c}\text { moderate to } \\
\text { profound }\end{array}$ & prelingual & & & British & [27] \\
\hline $\mathrm{AD}$ & c.710C >T; p.Thr237Ile & 5 & ENT & moderate & postlingual & stable & high & Korean & {$[28]$} \\
\hline $\mathrm{AD}$ & c.775G>C; p.Gly259Arg & 5 & & $\begin{array}{c}\text { moderate to } \\
\text { severe }\end{array}$ & postlingual & progressive & all & Italian & [29] \\
\hline $\mathrm{AD}$ & c.950T>A; p.Val317Glu & 6 & $\mathrm{ZA}$ & +2 & postlingual & & high & Korean & {$[30]$} \\
\hline AR & c.990C>A; p.Tyr330* & 6 & $\begin{array}{c}\text { ZA } \\
\text { (vWFD1) }\end{array}$ & severe & prelingual & & & Chinese & [31] \\
\hline $\mathrm{AD}$ & c.1084A>T; p.Ser362Cys & 6 & $\begin{array}{c}\text { ZA } \\
(\mathrm{vWFD1)}\end{array}$ & & postlingual & & mid & American & [25] \\
\hline $\mathrm{AD}$ & c.1124delT; p.Val375Alafs*4 & 6 & $\begin{array}{c}\text { ZA } \\
\text { (vWFD1) }\end{array}$ & 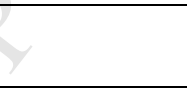 & postlingual & & mid & Spanish & {$[25]$} \\
\hline $\mathrm{AD}$ & c.1395T>G; p.Asn465Lys & 7 & $\begin{array}{c}\text { ZA } \\
\text { (vWFD1) }\end{array}$ & & postlingual & progressive & mid & Belgian & {$[25]$} \\
\hline $\mathrm{AR}$ & c.1471C>T; p.Arg491Cys & 7 & $\begin{array}{c}\text { ZA } \\
(\mathrm{vWFD1}) \\
\end{array}$ & profound & prelingual & progressive & mid & Japanese & [26] \\
\hline $\mathrm{AD}$ & c.1685C>T; p.Thr562Met & 7 & $\mathrm{ZA}$ & & postlingual & & mid & American & {$[25]$} \\
\hline AR & c. $2428 \mathrm{C}>\mathrm{T} ;$ p.Arg810* & 9 & $\begin{array}{c}\text { ZA } \\
\text { (vWFD2) }\end{array}$ & & prelingual & & & British & [32] \\
\hline $\mathrm{AD}$ & c.2444C>T; p.Thr815Met ${ }^{\mathrm{a}}$ & 9 & $\begin{array}{c}\mathrm{ZA} \\
\text { (vWFD2) } \\
\end{array}$ & & prelingual & & mid & American & {$[25]$} \\
\hline $\mathrm{AR}$ & c.2592C>A; p.Asn864Lys & 9 & $\mathrm{ZA}$ & moderate to & prelingual & & & British & [27] \\
\hline
\end{tabular}




\begin{tabular}{|c|c|c|c|c|c|c|c|c|c|}
\hline & & & (vWFD2) & profound & & & & & \\
\hline $\mathrm{AD}$ & c.2657A>G; p.Asn886Ser ${ }^{a}$ & 9 & $\begin{array}{c}\text { ZA } \\
\text { (vWFD2) }\end{array}$ & & prelingual & progressive & high & British & [25] \\
\hline AR & c. $2941+1 \mathrm{G}>\mathrm{A}$ & intron 9 & $\mathrm{ZA}$ & $\begin{array}{l}\text { severe to } \\
\text { profound }\end{array}$ & prelingual & & all & Lebanese & {$[33]$} \\
\hline $\mathrm{AD}$ & c.3107G>A; p.Cys1036Tyr & 10 & $\begin{array}{c}\mathrm{ZA} \\
\text { (TIL2) }\end{array}$ & & postlingual & stable & mid & Spanish & {$[25]$} \\
\hline $\mathrm{AR}$ & c.3123G>C; p.Glu1041Asp & 10 & $\mathrm{ZA}$ & & prelingual & 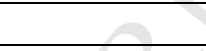 & & British & {$[32]$} \\
\hline $\mathrm{AD}$ & c.3169T>A; p.Cys1057Ser & 10 & $\mathrm{ZA}$ & $\begin{array}{c}\text { mild to } \\
\text { severe }\end{array}$ & postlingual & progressive & high & Swedish & {$[34]$} \\
\hline $\mathrm{AD}$ & c.3293C >T; pAla1098Val & 10 & $\mathrm{ZA}$ & & postlingual & +2 & high & Spanish & {$[25]$} \\
\hline $\mathrm{AD}$ & c.3406G >C; p.Asp1136His ${ }^{a}$ & 10 & $\begin{array}{c}\text { ZA } \\
\text { (vWFD3) }\end{array}$ & & postlingual & & high & Spanish & {$[25]$} \\
\hline $\mathrm{AD}$ & c.3743C $>$ T; p.Pro1248Leu ${ }^{a}$ & 11 & $\begin{array}{c}\text { ZA } \\
\text { (vWFD3) }\end{array}$ & & prelingual & & high & Spanish & {$[25]$} \\
\hline $\mathrm{AR}$ & c.3903C>A; p.Cys1301* & 11 & $\begin{array}{c}\mathrm{ZA} \\
\text { (vWFD3) }\end{array}$ & moderate & prelingual & stable & & Iranian & {$[35]$} \\
\hline $\mathrm{AR}$ & c.4055G>A; p.Cys1352Tyr & 11 & $\mathrm{ZA}$ & $\begin{array}{c}\text { moderate to } \\
\text { profound }\end{array}$ & prelingual & & & British & {$[27]$} \\
\hline $\mathrm{AD}$ & c.4198C >T; p.His1400Tyr & 12 & $\begin{array}{c}\text { ZA } \\
\text { (TIL3) }\end{array}$ & & postlingual & & & Japanese & {$[36]$} \\
\hline $\mathrm{AD}$ & c.4525T>G; p.Cys1509Gly & 13 & $\begin{array}{c}\mathrm{ZA} \\
\text { (vWFD4) }\end{array}$ & & & progressive & high & Turkish & [37] \\
\hline $\mathrm{AD}$ & c.4549T>C; p.Cys1517Arg & 13 & $\begin{array}{c}\mathrm{ZA} \\
\text { (vWFD4) }\end{array}$ & & postlingual & & high & Spanish & {$[25]$} \\
\hline $\mathrm{AD}$ & c.4856G>C; p.Cys1619Ser & 14 & $\begin{array}{c}\mathrm{ZA} \\
(\mathrm{vWFD} 4)\end{array}$ & $\begin{array}{c}\text { mild to } \\
\text { moderate- } \\
\text { severe }\end{array}$ & variable & progressive & high & French & {$[38]$} \\
\hline $\mathrm{AR}$ & c.4857C>A; p.Cys1619* & 14 & $\begin{array}{c}\text { ZA } \\
\text { (vWFD4) }\end{array}$ & profound & prelingual & & & Palestinian & [39] \\
\hline $\mathrm{AR}$ & c.5072G>T; p.Cys1691Phe & 15 & $\begin{array}{c}\mathrm{ZA} \\
\text { (vWFD4) }\end{array}$ & $\begin{array}{c}\text { moderate to } \\
\text { severe }\end{array}$ & prelingual & stable & & Korean & {$[40]$} \\
\hline AR & c.5211C>A; p.Tyr1737* & 15 & $\mathrm{ZA}$ & $\begin{array}{c}\text { moderate to } \\
\text { severe }\end{array}$ & prelingual & stable & mid & Iranian & {$[22]$} \\
\hline $\mathrm{AR}$ & c.5210A>G; p.Tyr1737Cys & 15 & ZA & & prelingual & & & Iranian & [41] \\
\hline $\mathbf{A R}$ & c.5272+1G>A & $\begin{array}{c}\text { intron } \\
15 \\
\end{array}$ & $\mathbf{Z A}$ & $\begin{array}{l}\text { moderate } \\
\text { to severe }\end{array}$ & prelingual & stable & all & Algerian & This study \\
\hline AR & c.5317C>T; p.Arg1773* & 16 & ZA & & & & & Japanese & {$[42]$} \\
\hline
\end{tabular}




\begin{tabular}{|c|c|c|c|c|c|c|c|c|c|}
\hline AD & c.5331G>A; p.Leu1777Leu & 16 & ZA & & prelingual & stable & mid & Dutch & [43] \\
\hline $\mathrm{AD}$ & c.5372C>G; p.Pro1791Arg & 16 & $\mathrm{ZA}$ & & prelingual & & high & American & [25] \\
\hline $\mathrm{AD}$ & c. $5383+2 \mathrm{~T}>\mathrm{G}$ & intron 16 & ZA & & prelingual & stable & mid & Spanish & {$[25]$} \\
\hline $\mathrm{AD}$ & c.5383+5delGTGA & intron 16 & $\mathrm{ZA}$ & & prelingual & & high & British & {$[25]$} \\
\hline $\mathrm{AD}$ & c.5458C > T; p.Leu1820Phe & 17 & $\mathrm{ZP}$ & $\begin{array}{c}\text { mild to } \\
\text { severe }\end{array}$ & postlingual & stable & mid & Belgian & [44] \\
\hline $\mathrm{AD}$ & c.5471G>A; p.Gly1824Asp & 17 & $\mathrm{ZP}$ & $\begin{array}{l}\text { mild to } \\
\text { severe }\end{array}$ & postlingual & stable & mid & Belgian & [44] \\
\hline $\mathrm{AD}$ & c.5509T>G; p.Cys 1837 Gly & 17 & $\mathrm{ZP}$ & $\begin{array}{l}\text { mild to } \\
\text { severe }\end{array}$ & postlingual & progressive & mid & Spanish & {$[25,45]$} \\
\hline $\mathrm{AD}$ & c.5509T>C; p.Cys1837Arg & 17 & $\mathrm{ZP}$ & $\begin{array}{l}\text { mild to } \\
\text { moderate }\end{array}$ & postlingual & progressive & mid & American & {$[22]$} \\
\hline $\mathrm{AD}$ & c.5597C>T; p.Thr1866Met & 18 & $\mathrm{ZP}$ & $\begin{array}{l}\text { mild to } \\
\text { moderate }\end{array}$ & postlingual & $\begin{array}{c}\text { stable/ } \\
\text { progressive }\end{array}$ & mid & $\begin{array}{c}\text { Korean/Spanish/ } \\
\text { American }\end{array}$ & {$[25,30]$} \\
\hline $\mathrm{AD}$ & c.5600A>G; p.His1867Arg & 18 & $\mathrm{ZP}$ & & postlingual & progressive & mid & Spanish & {$[25]$} \\
\hline $\mathrm{AD}$ & c.5609A>G; p.Tyr1870Cys & 18 & $\mathrm{ZP}$ & $\begin{array}{c}\text { moderate to } \\
\text { severe }\end{array}$ & prelingual & stable & mid & Austrian & [44] \\
\hline $\mathrm{AD}$ & c.5618 C>T; p.Thr1873Ile & 18 & $\mathrm{ZP}$ & moderate & +8 & stable & mid & Korean & {$[46]$} \\
\hline $\mathrm{AD}$ & c.5668C >T; p.Arg1890Cys & 18 & $\mathrm{ZP}$ & $\begin{array}{l}\text { mild to } \\
\text { moderate }\end{array}$ & prelingual & stable & mid & $\begin{array}{c}\text { Dutch/Spanish/ } \\
\text { American }\end{array}$ & {$[25,47]$} \\
\hline $\mathrm{AD}$ & c.5692T>C; p.Cys1898Arg & 18 & $\mathrm{ZP}$ & & postlingual & & mid & American & {$[25]$} \\
\hline $\mathrm{AD}$ & c.5839C>T; p.Arg1947Cys & 19 & $\mathrm{ZP}$ & $2 \times 1$ & postlingual & & mid & American & {$[25]$} \\
\hline $\mathrm{AD}$ & c.5945C>A; p.Ala1982Asp & 19 & $\mathrm{ZP}$ & $\begin{array}{l}\text { moderate to } \\
\text { severe }\end{array}$ & prelingual & progressive & all & Chinese & {$[48]$} \\
\hline $\mathrm{AD}$ & c.5990T>C; p.Ile1997Thr & 19 & $\mathrm{ZP}$ & & prelingual & progressive & mid & Japanese & {$[36]$} \\
\hline $\mathrm{AD}$ & c.6016G>T; p.Asp2006Tyr & 20 & $\mathrm{ZP}$ & severe & prelingual & & mid & Mongolian & [49] \\
\hline $\mathrm{AD}$ & c.6026T>C; p.Ile2009Thr & 20 & $\mathrm{ZP}$ & & postlingual & stable & high & Spanish & {$[25]$} \\
\hline $\mathrm{AD}$ & c. $6062 \mathrm{G}>\mathrm{A}$; p.Arg2021His & 20 & $\mathrm{ZP}$ & $\begin{array}{l}\text { mild to } \\
\text { moderate }\end{array}$ & prelingual & stable & mid & Japanese & {$[50]$} \\
\hline AR & $\begin{array}{c}\text { c.6037delG; } \\
\text { p.Glu2013Argfs*6 }\end{array}$ & 20 & $\mathrm{ZP}$ & $\begin{array}{c}\text { moderate to } \\
\text { severe }\end{array}$ & prelingual & stable & $\begin{array}{l}\text { mid } \\
\text { (flat to shallow U- } \\
\text { shaped audiogram) }\end{array}$ & Pakistani & {$[23]$} \\
\hline AR & c. $6162+3$ ins $T$ & intron 20 & $\mathrm{ZP}$ & $\begin{array}{c}\text { moderate to } \\
\text { severe }\end{array}$ & prelingual & stable & & Korean & {$[40]$} \\
\hline
\end{tabular}




\begin{tabular}{|c|c|c|c|c|c|c|c|c|}
\hline AR & $\begin{array}{c}\text { c.6203_6218del; } \\
\text { p.Lys2068Argfs*38 }\end{array}$ & 21 & ZP & moderate & prelingual & stable & $\begin{array}{c}\text { all } \\
\text { (flat to shallow U } \\
\text { shaped audiogram) }\end{array}$ & Iranian \\
\hline
\end{tabular}

AD, autosomal dominant (DFNA8/12)

AR, autosomal recessive (DFNB21)

${ }^{a}$ Pathogenicity questionable 
A

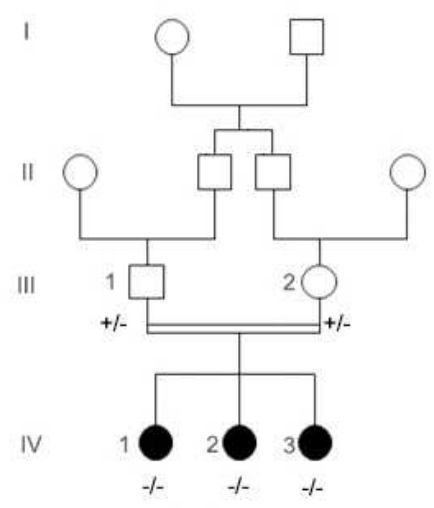

C

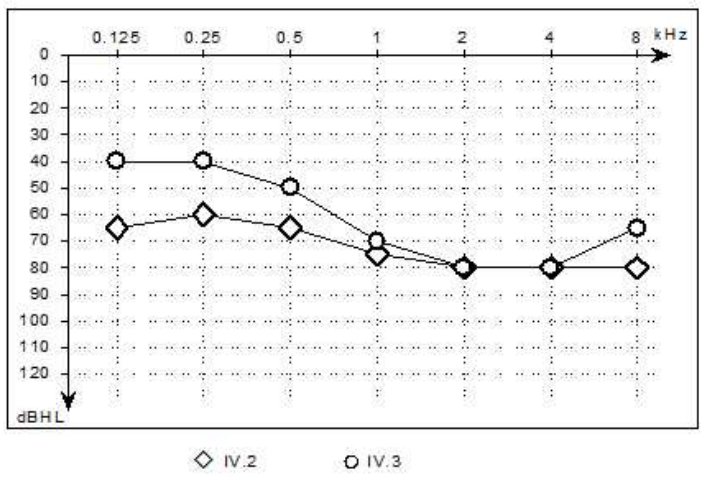

B

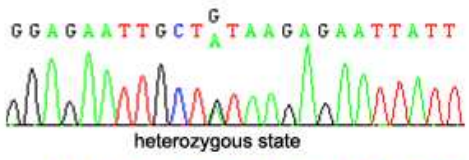
GGAGARTTGCTATAAGAGA $T$ TATT

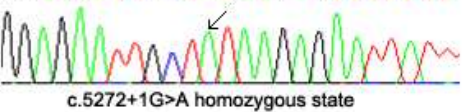

GGAGAATTGCTGTAAGAGAATTATT

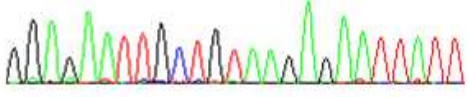

reference sequence

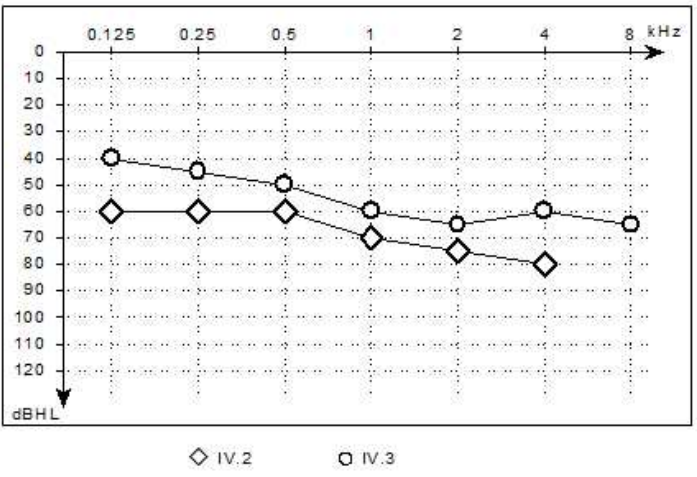

D

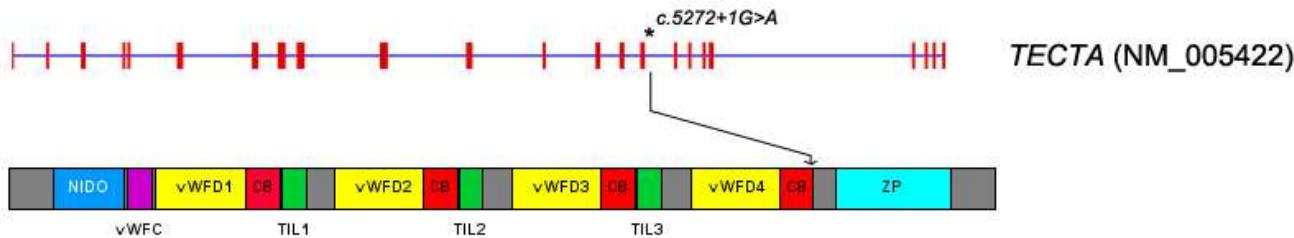

